\title{
Sources of Conductance Changes during Bacterial Reduction of Trimethylamine Oxide to Trimethylammonium in Phosphate Buffer
}

\author{
By J. D. OWENS, ${ }^{*}$ D. R. MISKIN, $\dagger$ M. C. WACHER-VIVEROS $\ddagger$ AND \\ L. C. A. BENGE \\ Department of Food Technology, University of Reading, Whiteknights, PO Box 226, \\ Reading RG6 $2 A P, U K$
}

(Received 13 November 1984 ; revised 6 February 1985)

\begin{abstract}
The sources of conductance changes during reduction of trimethylamine oxide to trimethylamine by Escherichia coli with formate as electron donor and in the presence of phosphate buffer were investigated. Theoretical considerations and experimental results suggest that the major source of conductance change is the conversion of dihydrogen phosphate to hydrogen phosphate. This transformation contributes almost twice as much to the total conductance change as does the conversion of uncharged trimethylamine oxide to charged trimethylammonium.
\end{abstract}

\section{INTRODUCTION}

The monitoring of conductance changes in microbial cultures is finding increasing application as a relatively rapid, automated method for the enumeration of micro-organisms in routine food and medical samples (McMurdo \& Whyard, 1984). But wider use of the methodology is hindered by a lack of understanding of the mechanisms by which microbial growth brings about changes in the conductance of culture media (Firstenberg-Eden \& Eden, 1984).

Easter et al. (1982) described a conductance method for studying the reduction of trimethylamine oxide (TMAO) by bacterial cultures or enzyme preparations. They demonstrated a linear relationship between reduction of TMAO to trimethylammonium $\left(\mathrm{TMAH}^{+}\right)$ and change in the conductance of the medium. They ascribed this change in conductance 'mainly to the molecular charge of TMA compared with TMAO' and stated that 'It is not simply due to a $\mathrm{pH}$ change or the apparatus being a sensitive $\mathrm{pH}$ meter'. However, since their assay systems contained phosphate buffer, it is possible that much of the change in conductance was, in fact, due to changes in the proportions of dihydrogen phosphate and hydrogen phosphate ions. Since the amount of phosphate transformed will be proportional to the amount of TMAO reduced, this does not affect the validity of the assay method. But, if the rational formulation of culture media for conductimetric assays is to be attempted, it is important that the sources of conductance changes in cultures are correctly distinguished.

\footnotetext{
† Present address: North Lindsey College of Technology, Kingsway, Scunthorpe, UK.

$\ddagger$ Present address: Departamento de Alimentos, Facultad de Quimica, Universidad Nacional Autonoma de Mexico, Mexico.

Abbreviations: $\mathrm{TMAH}^{+}$, trimethylammonium; TMAO, trimethylamine oxide.
} 


\section{THEORY}

Taking formate as the electron donor, the reduction of TMAO in the presence of phosphate buffer (in the range pH 7.0-8.2) in a sealed system (to retain carbon dioxide) can be represented as:

$$
\begin{gathered}
\left(\mathrm{CH}_{3}\right)_{3} \mathrm{NO}+3 \mathrm{H}^{+}+2 \mathrm{e}^{-} \rightarrow\left(\mathrm{CH}_{3}\right)_{3} \mathrm{NH}^{+}+\mathrm{H}_{2} \mathrm{O} \\
\mathrm{HCOO}^{-}+\mathrm{H}_{2} \mathrm{O} \rightarrow \mathrm{HCO}_{3}^{-}+2 \mathrm{H}^{+}+2 \mathrm{e}^{-} \\
\mathrm{H}_{2} \mathrm{CO}_{3} \leftrightharpoons \mathrm{HCO}_{3}^{-}+\mathrm{H}^{+} \leftrightharpoons \mathrm{CO}_{3}^{2-}+2 \mathrm{H}^{+} \\
\mathrm{H}_{2} \mathrm{PO}_{4}^{-} \rightarrow \mathrm{HPO}_{4}^{2-}+\mathrm{H}^{+}
\end{gathered}
$$

At pH 7.0 approximately $80 \%$ of the carbon dioxide will be present as the bicarbonate ion and at higher $\mathrm{pH}$ values this percentage increases. Most of the remainder will be present as carbon dioxide or undissociated carbonic acid $\left(\mathrm{pK}_{1}, 6 \cdot 38 ; \mathrm{pK}_{2}, 10 \cdot 32\right)$. Hence, if the carbon dioxide and carbonic acid are neglected the sum of the above equations may be written:

$$
\left(\mathrm{CH}_{3}\right)_{3} \mathrm{NO}+\mathrm{HCOO}^{-}+\mathrm{H}_{2} \mathrm{PO}_{4}^{-} \rightarrow\left(\mathrm{CH}_{3}\right)_{3} \mathrm{NH}^{+}+\mathrm{HCO}_{3}^{-}+\mathrm{HPO}_{4}^{2-}
$$

Current is carried in solution only by molecules bearing a net charge and thus the conductance of the system will change due to: (i) reduction of uncharged TMAO to charged $\mathrm{TMAH}^{+}$, (ii) oxidation of formate to bicarbonate, and (iii) conversion of dihydrogen phosphate to hydrogen phosphate. Thus the change in conductance of the system per mole of TMAO reduced is given by:

$$
\Delta \Lambda=\Lambda_{\mathrm{TMAH}^{+}}+\left(\Lambda_{\mathrm{HCO}_{3}^{-}}-\Lambda_{\mathrm{HCOO}^{-}}\right)+\left(\Lambda_{\mathrm{HPO}_{4}^{2-}}-\Lambda_{\mathrm{H}_{2} \mathrm{PO}_{4}^{-}}\right)
$$

where $\Lambda$ is the molar conductivity of the respective ions.

It is not possible to calculate accurately the molar conductivities of ions in complex mixtures. However, as a first approximation, it may be assumed that the molar conductivities of the different ions are proportionately decreased by similar amounts from their values at infinite dilution. Thus, for the purposes of comparing the relative contributions of each of the above transformations to the total change in conductance, molar conductivities at infinite dilution may be used. Substituting the values given by Erdey-Gruz (1974), Parsons (1959) or Stark \& Wallace (1982) in equation (2):

$$
\begin{aligned}
\Delta \Lambda_{0} & =4.2+(4.45-5.46)+(11.4-3.6) \\
& =4.2+(-1.01)+7.8 \\
& =10.99 \mathrm{mS} \mathrm{m}{ }^{2}(\text { mol TMAO reduced })^{-1}
\end{aligned}
$$

It is evident that, in this system, the contribution of the phosphate transformations to the total conductance change is almost double that due to the production of $\mathrm{TMAH}^{+}$.

Transformation of the phosphates must necessarily be accompanied by change in the $\mathrm{pH}$ of the mixture. Calculation of the extent of this change must take account of buffering by both phosphate and carbonic acid/bicarbonate. From equation (1), the $\mathrm{pH}$ following the reduction of a particular amount of TMAO is given by:

$$
\mathrm{pH}=\mathrm{pK}_{2}^{\mathrm{P}^{\prime}}+\log \left(\frac{\left[\mathrm{HPO}_{4}^{2-}\right]_{0}+\left[\mathrm{TMAH}^{+}\right]_{1}}{\left[\mathrm{H}_{2} \mathrm{PO}_{4}^{-}\right]_{0}-\left[\mathrm{TMAH}^{+}\right]_{1}}\right)
$$

where $\mathrm{pK}_{2}^{\mathrm{P}^{\prime}}$ is the second dissociation constant for phosphoric acid at the prevailing ionic strength, $I$ [i.e. $\mathrm{pK}_{2}^{\mathrm{P}^{\prime}}=\mathrm{pK}_{2}^{\mathrm{P}}-1.53\left\{I^{1 / 2}\left(1+I^{1 / 2}\right)^{-1}-0.2 I\right\}$ in water at $25^{\circ} \mathrm{C}$; Butler, 1982], $\left[\mathrm{HPO}_{4}^{2-}\right]_{0}$ is the initial concentration of hydrogen phosphate, $\left[\mathrm{H}_{2} \mathrm{PO}_{4}^{-}\right]_{0}$ is the initial concentration of dihydrogen phosphate, and $\left[\mathrm{TMAH}^{+}\right]_{1}$ is the concentration of $\mathrm{TMAH}^{+}$ formed. But since, at $\mathrm{pH}$ values below about 8 , the bicarbonate is in equilibrium with carbonic acid (actually mainly present as carbon dioxide) the change in $\mathrm{pH}$ is greater than given by (4):

$$
\mathrm{HCO}_{3}^{-}+\mathrm{H}_{2} \mathrm{PO}_{4}^{-} \leftrightharpoons \mathrm{H}_{2} \mathrm{CO}_{3}+\mathrm{HPO}_{4}^{2-}
$$


Thus, allowing for this, the $\mathrm{pH}$ is given by:

$$
\mathrm{pH}=\mathrm{pK}_{2}^{\mathrm{P}^{\prime}}+\log \left(\frac{\left[\mathrm{HPO}_{4}^{2-}\right]_{0}+\left[\mathrm{TMAH}^{+}\right]_{1}+\left[\mathrm{H}_{2} \mathrm{CO}_{3}\right]_{1}}{\left[\mathrm{H}_{2} \mathrm{PO}_{4}^{-}\right]_{0}-\left[\mathrm{TMAH}^{+}\right]_{1}-\left[\mathrm{H}_{2} \mathrm{CO}_{3}\right]_{1}}\right)
$$

and since

$$
\begin{gathered}
{\left[\mathrm{H}_{2} \mathrm{CO}_{3}\right]_{1}+\left[\mathrm{HCO}_{3}^{-}\right]_{1}=\left[\mathrm{TMAH}^{+}\right]_{1}} \\
\mathrm{pH}=\mathrm{pK}_{2}^{\mathrm{P}^{\prime}}+\log \left(\frac{\left[\mathrm{HPO}_{4}^{2-}\right]_{0}+2\left[\mathrm{TMAH}^{+}\right]_{1}-\left[\mathrm{HCO}_{3}^{-}\right]_{1}}{\left[\mathrm{H}_{2} \mathrm{PO}_{4}^{-}\right]_{0}-2\left[\mathrm{TMAH}^{+}\right]_{1}+\left[\mathrm{HCO}_{3}^{-}\right]_{1}}\right)
\end{gathered}
$$

where $\left[\mathrm{H}_{2} \mathrm{CO}_{3}\right]_{1}$ is the concentration of carbonic acid after reduction of the TMAO and $\left[\mathrm{HCO}_{3}^{-}\right]_{1}$ is the concentration of bicarbonate after reduction of the TMAO. The only unknown in this equation, apart from $\mathrm{pH}$, is $\left[\mathrm{HCO}_{3}^{-}\right]_{1}$ which may be determined as follows.

Since

$$
\left[\mathrm{H}^{+}\right]_{1}=\frac{\mathrm{K}_{1}^{\mathrm{C}^{\prime}}\left(\mathrm{C}_{1}^{\mathrm{C}}-\left[\mathrm{HCO}_{3}^{-}\right]_{1}\right)}{\left[\mathrm{HCO}_{3}^{-}\right]_{1}}
$$

and

$$
\left[\mathrm{H}^{+}\right]_{1}=\frac{\mathrm{K}_{2}^{\mathrm{P}^{\prime}}\left[\mathrm{H}_{2} \mathrm{PO}_{4}^{-}\right]_{1}}{\left[\mathrm{HPO}_{4}^{2-}\right]_{1}}
$$

then

$$
\frac{\mathrm{K}_{1}^{\mathrm{C}^{\prime}}\left(\mathrm{C}_{1}^{\mathrm{C}}-\left[\mathrm{HCO}_{3}^{-}\right]_{1}\right)}{\left[\mathrm{HCO}_{3}^{-}\right]_{1}}=\frac{\mathrm{K}_{2}^{\mathrm{P}^{\prime}}\left(\left[\mathrm{H}_{2} \mathrm{PO}_{4}^{-}\right]_{\mathrm{t}}+\left[\mathrm{HCO}_{3}^{-}\right]_{1}\right)}{\left[\mathrm{HPO}_{4}^{2-}\right]_{\mathrm{t}}-\left[\mathrm{HCO}_{3}^{-}\right]_{1}}
$$

where $\mathrm{K}_{1}^{\mathrm{C}^{\prime}}$ is the first dissociation constant for carbonic acid at the prevailing ionic strength $\left[\mathrm{pK}_{1}^{\mathrm{C}^{\prime}}=\mathrm{pK}_{1}^{\mathrm{C}}+0.51\left\{I^{1 / 2}\left(1+I^{1 / 2}\right)^{-1}-0.2 I\right\}\right.$ in water at $\left.25^{\circ} \mathrm{C}\right], \mathrm{C}_{1}^{\mathrm{C}}$ is the total amount of $\mathrm{CO}_{2}$ produced (i.e. $\left[\mathrm{H}_{2} \mathrm{CO}_{3}\right]_{1}+\left[\mathrm{HCO}_{3}^{-}\right]_{1}=\left[\mathrm{TMAH}^{+}\right]_{1}$ ),

$$
\begin{aligned}
{\left[\mathrm{H}_{2} \mathrm{PO}_{4}^{-}\right]_{\mathrm{t}} } & =\left[\mathrm{H}_{2} \mathrm{PO}_{4}^{-}\right]_{0}-2\left[\mathrm{TMAH}^{+}\right]_{1}, \text { and } \\
{\left[\mathrm{HPO}_{4}^{2-}\right]_{\mathrm{t}} } & =\left[\mathrm{HPO}_{4}^{2-}\right]_{0}+2\left[\mathrm{TMAH}^{+}\right]_{1} .
\end{aligned}
$$

Rearranging:

$$
\begin{aligned}
\left(\mathrm{K}_{1}^{\mathrm{C}^{\prime}}-\mathrm{K}_{2}^{\mathrm{P}^{\prime}}\right)\left(\left[\mathrm{HCO}_{3}^{-}\right]_{1}\right)^{2}- & \left(\mathrm{K}_{1}^{\mathrm{C}^{\prime}} \mathrm{C}_{1}^{\mathrm{C}}+\mathrm{K}_{1}^{\mathrm{C}^{\prime}}\left[\mathrm{HPO}_{4}^{2-}\right]_{\mathrm{t}}+\mathrm{K}_{2}^{\mathrm{P}^{\prime}}\left[\mathrm{H}_{2} \mathrm{PO}_{4}^{-}\right]_{\mathrm{t}}\right)\left[\mathrm{HCO}_{3}^{-}\right]_{1} \\
& +\mathrm{K}_{1}^{\mathrm{C}^{\prime}} \mathrm{C}_{1}^{\mathrm{C}_{1}}\left[\mathrm{HPO}_{4}^{2-}\right]_{\mathrm{t}}=0
\end{aligned}
$$

$\left[\mathrm{HCO}_{3}^{-}\right]_{1}$ can thus be calculated by solving this quadratic equation and the new $\mathrm{pH}$ value of the solution determined with equation (6). Iteration of this procedure yields values for the final concentrations of all the components of the system.

The work reported in this paper attempts to confirm the above interpretation by monitoring the conductivity and $\mathrm{pH}$ changes during the reduction of TMAO by Escherichia coli with formate as electron donor and in the presence of phosphate buffer.

\section{METHODS}

Measurement of conductivity. Conductivity of solutions was measured with a Schott Gerate conductivity meter (model CG857; Boro Laboratories, Aldermaston, Berks, UK) using alternating current at $1000 \mathrm{~Hz}$ and a dip type electrode having a cell constant of approximately $1 \mathrm{~cm}^{-1}$ (Schott Gerate LF3100). An accurate cell constant was determined using $0 \cdot 01$ and $0 \cdot 1 \mathrm{M}-\mathrm{KCl}$ and recorded conductivity values were appropriately corrected. The $\mathrm{KCl}$ solutions were made with freshly collected distilled water and were stored under soda lime tubes but further precautions to exclude $\mathrm{CO}_{2}$ were not taken. Measurements were made in a constant temperature room at $25^{\circ} \mathrm{C}$.

Chemicals. TMAO was obtained from Sigma and other chemicals were from BDH or Fisons and were of Analar grade or the purest grade otherwise available. Before use they were dried either at $105^{\circ} \mathrm{C}$ or over $\mathrm{P}_{2} \mathrm{O}_{5}$ at ambient temperature.

Distilled water was made by distilling water from a reverse osmosis water purifier (Millipore RO60) in a glass still (Corning Aquatron; Bibby Science Products, Stone, Staffs., UK). Freshly collected distilled water had a conductivity of $0 \cdot 12-0.2 \mathrm{mS} \mathrm{m}^{-1}$ at $25^{\circ} \mathrm{C}$.

Bacterial suspension. Escherichia coli $\mathrm{K} 12$ was grown in a medium containing $\left(\mathrm{g} \mathrm{l}^{-1}\right)$ : tryptone (Oxoid L42), 10; yeast extract (Oxoid L21), 5; $\mathrm{K}_{2} \mathrm{HPO}_{4}, 12 ; \mathrm{KH}_{2} \mathrm{PO}_{4}, 3 ; \mathrm{NaCl}, 5$; glycerol, 5; TMAO, 10; $\mathrm{pH}, 7 \cdot 3$. The medium, without TMAO, was sterilized by autoclaving at $121^{\circ} \mathrm{C}$ for $10 \mathrm{~min}$ and filter sterilized TMAO solution, $100 \mathrm{~g}^{-1}$, was then aseptically added to it. The medium was aseptically dispensed into $250 \mathrm{ml}$ screw-capped bottles which were completely filled. Cultures were incubated at $37^{\circ} \mathrm{C}$ for $1 \mathrm{~d}$ and the cells from 1 litre of culture were then 


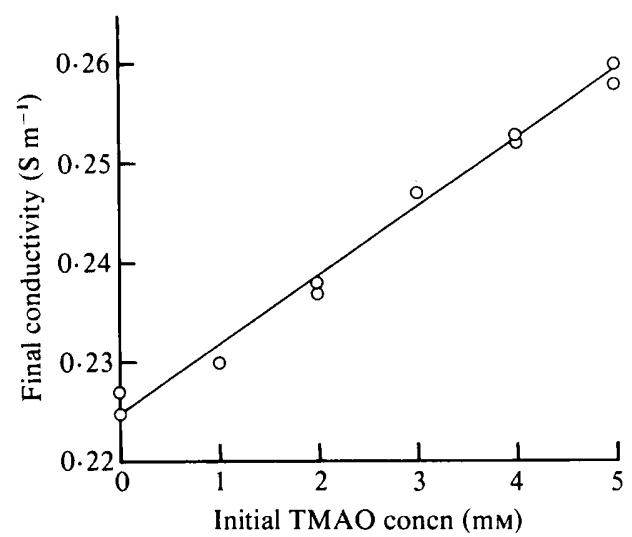

Fig. 1. Relationship between final conductivity value and initial concentration of TMAO following reduction of TMAO to $\mathrm{TMAH}^{+}$by $E$. coli in phosphate buffer.

harvested by centrifugation. Cells were washed twice in $10 \mathrm{~mm}$-potassium phosphate buffer, $\mathrm{pH} 6.9$, containing 23 drops of $\beta$-mercaptoethanol $1^{-1}$, resuspended in $40 \mathrm{ml}$ of the same buffer, and stored at $4{ }^{\circ} \mathrm{C}$ until required. The suspension contained $5.6 \mathrm{~g}$ dry matter $\mathrm{I}^{-1}$.

Bacterial reduction of TMAO. Reaction mixtures comprised $(\mathrm{ml}): 10 \mathrm{~mm}$-potassium phosphate buffer $\mathrm{pH} 6 \cdot 9,9$; $50 \mathrm{mM}$-sodium formate, 4 ; bacterial suspension, 1; $40 \mathrm{mM}$-TMAO, as required; distilled water, to 20 . Mixtures were contained in $150 \times 16 \mathrm{~mm}$ test-tubes and partially sealed from air by floating a small test-tube on the liquid surface and closing the mouth of the $16 \mathrm{~mm}$ test-tube with a rubber bung. Tubes were incubated at $25^{\circ} \mathrm{C}$ and the $\mathrm{pH}$ and conductivity measured after 2 and $3 \mathrm{~h}$. Each test was done in duplicate. The presence of TMAH $\mathrm{TM}^{+}$in tubes after incubation was obvious due to its very distinctive smell.

\section{RESULTS}

The final conductivities of reaction mixtures containing different initial amounts of TMAO are shown in Fig. 1. The results show the expected linear relationship between conductivity change and initial concentration of TMAO, with a slope of $6.9 \mathrm{mS} \mathrm{m}^{2}$ (mol TMAO reduced) $)^{-1}$. The final $\mathrm{pH}$ values of the mixtures were very close to those predicted by calculation using equation (6) (Table 1). Except in the tubes containing the highest initial concentration of TMAO, the $\mathrm{pH}$ and conductivity values after $3 \mathrm{~h}$ incubation were similar to those recorded after $2 \mathrm{~h}$, showing that the reactions had gone to completion.

\section{DISCUSSION}

The closeness of the final $\mathrm{pH}$ values of the experimental reaction mixtures to the predicted values provides good evidence for the reaction pathways proposed.

Although the observed change in conductivity of $6.9 \mathrm{mS} \mathrm{m}^{2}$ (mol TMAO reduced) ${ }^{-1}$ is substantially less than the theoretical maximum of $10.99 \mathrm{mS} \mathrm{m}^{2} \mathrm{~mol}^{-1}$ at infinite dilution, it is almost double the theoretical maximum obtainable from production of $\mathrm{TMAH}^{+}$alone without any contribution from phosphate transformations. It is clear, therefore, that phosphate transformations are a major source of conductance change in the system studied and that this will generally be the case for the reduction of TMAO with most electron donors in the presence of phosphate buffer. It may be presumed, from the theoretical predictions, that the contribution from the phosphate transformations is nearly double that due to the formation of $\mathrm{TMAH}^{+}$. It also follows that the sensitivity of conductance change as an assay for the reduction of TMAO is higher $\left(10.99 \mathrm{mS} \mathrm{m}^{2} \mathrm{~mol}^{-1}\right.$ at infinite dilution) in the presence of $\mathrm{pH}$ changes in phosphate buffer than it would be in the absence of such changes $\left(3-4 \mathrm{mS} \mathrm{m}^{2} \mathrm{~mol}^{-1}\right)$. However, the exploitation of such increased response is dependent on a clear understanding of the reactions involved, since with different electron donors and/or oxidized products quite different changes in conductivity per mole of TMAO reduced may be obtained (Table 2). 
Table 1. Calculated and experimentally determined final $\mathrm{pH}$ values of reaction mixtures following the bacterial reduction of TMAO to TMAH ${ }^{+}$in phosphate buffer

The initial reaction mixture contained $9.5 \mathrm{~mm}$-phosphate buffer, $50 \mathrm{~mm}$-sodium formate, $E$. coli suspension, and TMAO as required. Calculated values were determined as described in the text, taking $\mathrm{pK}_{2}^{\mathrm{P}}=7 \cdot 21$ and $\mathrm{pK}_{1}^{\mathrm{C}}=6 \cdot 38$.

\begin{tabular}{|c|c|c|c|}
\hline \multirow[b]{2}{*}{$\begin{array}{c}\text { Initial } \\
\text { TMAO concn } \\
\text { (mM) }\end{array}$} & \multicolumn{3}{|c|}{$\begin{array}{l}\mathrm{pH} \text { after reduction of } \\
\text { TMAO to } \text { TMAH }^{+}\end{array}$} \\
\hline & Calculated & $\begin{array}{r}\text { Expe } \\
\text { (duI }\end{array}$ & $\begin{array}{l}\text { ental } \\
\text { ites) }\end{array}$ \\
\hline 0 & $6.86^{*}$ & 6.87 & 6.90 \\
\hline 1 & 7.06 & 7.07 & 7.08 \\
\hline 2 & $7 \cdot 26$ & $7 \cdot 23$ & $7 \cdot 25$ \\
\hline 3 & $7 \cdot 48$ & $7 \cdot 43$ & $7 \cdot 46$ \\
\hline 4 & $7 \cdot 74$ & 7.67 & 7.67 \\
\hline 5 & $8 \cdot 33$ & 7.98 & $7 \cdot 98$ \\
\hline
\end{tabular}

Table 2. Calculated change in conductivity at infinite dilution due to the reduction of $T M A O$ with different electron donors in the presence of excess phosphate buffer

Oxidation-reduction reaction

$\mathrm{CH}_{3} \mathrm{CHO}+\mathrm{TMAO} \rightarrow \mathrm{CH}_{3} \mathrm{COO}^{-}+\mathrm{TMAH}^{+}$
$\mathrm{C}_{6} \mathrm{H}_{12} \mathrm{O}_{6}+12 \mathrm{TMAO}+6 \mathrm{H}^{+} \rightarrow 6 \mathrm{HCO}_{3}^{-}+12 \mathrm{TMAH}^{+}$
$\mathrm{HCOO}^{-}+\mathrm{TMAO}+\mathrm{H}^{+} \rightarrow \mathrm{HCO}_{3}^{-}+\mathrm{TMAH}^{+}$
$\mathrm{NADH}+\mathrm{TMAO}+2 \mathrm{H}^{+} \rightarrow \mathrm{NAD}^{+}+\mathrm{TMAH}^{+}+\mathrm{H}_{2} \mathrm{O}$

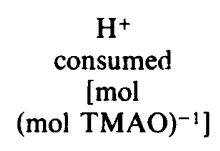

0

$0 \cdot 5^{*}$

$1 *$

2

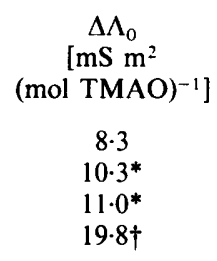

$\Delta \Lambda_{0}$ mol
TMAO m$\left.)^{-1}\right]$

$8 \cdot 3$

$11 \cdot 0^{*}$

$19 \cdot 8+$

${ }^{*}$ Calculated on the assumption that all $\mathrm{CO}_{2}$ is present as $\mathrm{HCO}_{3}^{-}$.

$\uparrow$ Not including contribution from $\mathrm{NAD}^{+}$.

Very many metabolic activities of micro-organisms lead to $\mathrm{pH}$ changes in culture media and it is possible, therefore, that a substantial proportion of the conductance change that occurs in cultures during growth might also be due to changes in the conductance of phosphate ions or other buffer compounds. If this is the case, it suggests that conductance changes in microbial cultures could be enhanced by the use of appropriate $\mathrm{pH}$ buffer compounds, with a consequent decrease in the time required for the enumeration of a given microbial population. The techniques used in this paper to estimate the relative contributions of different reactions to the overall conductance change provide a means for the selection of suitable buffers and for the rational formulation of culture media for conductimetric assays.

The authors thank Dr A. D. Pethybridge for advice, and D. R. Miskin thanks Humberside County Council for financial support.

\section{REFERENCES}

Butler, J. N. (1982). Carbon Dioxide Equilibria and their Applications, pp. 32-33. Reading, Mass.: Addison-Wesley.

EAster, M. C., Gibson, D. M. \& WARD, F. B. (1982). A conductance method for the assay and study of bacterial trimethylamine oxide reduction. Journal of Applied Bacteriology 52, 357-365.

ERDEY-GruZ, T. (1974). Transport Phenomena in Aqueous Solutions. London: Adam Hilger.

FIRSTENBERG-EDEN, R. \& EDEN, G. (1984). Impedance
Microbiology. Letchworth, UK: Research Studies Press.

MCMurdo, I. H. \& WHYARD, S. (1984). Suitability of rapid microbiological methods for the hygienic management of spray drier plant. Journal of the Society of Dairy Technology 37, 4-9.

PARSONS, R. (1959). Handbook of Electrochemical Constants. London: Butterworths.

StaRK, J. G. \& Wallace, I. G. (1982). Chemistry Data Book, 2nd edn. London: Murray. 